\title{
As religiões mundiais e a ética biocêntrica
}

\author{
Eva Aparecida Rezende de Moraes
}

\section{Resumo}

Este artigo trata da proposta da passagem de uma ética "antropocêntrica" para uma ética "biocêntrica". Entendemos que essa proposta se aproxima da ética desenvolvida pelas cinco maiores religiões mundiais.

Palavras-chave: Ética Antropocêntrica, Ética Biocêntrica, Religiões Mundiais.

\section{Abstract}

This paper aims to show a proposal on the shift from na antropocentric ethics to a biocentric ethics. It is assumed that this proposal is connected to the ethics developed by the five major religions in the worl.

Keywords: Antropocentric Ethics, Biocentric Ethics, Worl Religions.

Atualmente, a realidade tem desafiado a ética e como as religiões são intrinsecamente unidas à ética, também podem apresentar contribuições. A proposta dessas poucas linhas é a defesa da ética biocêntrica, o que pode ser 
ajudado pelas religiões mundiais. Nos demoraremos na religião cristã, apresentando, rapidamente, uma fundamentação teológica.

\section{1. Ética e Moral}

A Ética é uma ciência, um ramo da filosofia. Podemos nos perguntar como surgiu a Ética: se a entendemos como inerente ao ser humano, ela esteve presente desde o surgimento dos primeiros seres conscientes e sofreu evolução. Alguns autores já levantam essa hipótese: em 14 de janeiro de 2008, Steven Pinker, professor de Psicologia da Universidade de Harvard, escrevia um artigo no New York Times, intitulado "The Moral Instinct: Evolution has endowed us with ethical impulses. Do we know what to do with them?"1, onde levanta a possibilidade da existência da moralidade genética - o que, por sua vez, não inviabiliza nossas ações pessoais e sociais numa "educação ética". Pouco antes, em 2006, primatólogos defendiam essa tese, devido à evidente presença da moralidade humana em animais sociais ${ }^{2}$. Marc D. Hauser, biólogo da Universidade de Harvard, propõe que as pessoas nascem com uma "gramática moral" em seus circuitos neurais, feita pela evolução. Harper Collins, também em 2006, lançava seu livro Moral Minds, onde argumenta que essa "gramática" gera julgamentos morais instantâneos e que são inacessíveis à mente consciente. Robert Wright, em seu livro The Animal Moral, afirma que a moralidade é uma adaptação projetada para maximizar geneticamente o auto-interesse, uma função que é inteiramente escondida da nossa experiência consciente... OU seja, segundo esses autores, é preciso reconstruir a moral "de baixo para cima", na esteira de Darwin ${ }^{3} .$. Mas, se entendemos ética como ciência, então, a ética remonta aos gregos clássicos.

Ou seja: a própria história da ética depende do conceito que damos a ela. Em 1959, o autor Jose Luis L. Aranguren nos advertia de que definição não pode ser sinônimo de delimitação, visto serem vários e muito diferentes entre si os saberes com os quais a ética tem que ser delimitada ${ }^{4}$. Em 1975, o autor G. E. Moore destacava a criação da palavra ética pelos gregos: ethos significa

\footnotetext{
${ }^{1}$ Cf. "A Moral Gene. Ethics Blog". In: <http://www.ruderfinn.com/blogs/ethics/2008/01/a-moralgene.html>.

${ }^{2}$ Cf. “The moral gene". In: http://www.indianexpress.com/news/the-moral-gene/16009/

${ }^{3}$ Cf. PINKER, Steven. "Is There a Gene for Compassion?". In: <http://cogweb.ucla.edu/Abstracts/ Pinker_on_Wright_94.html>.

${ }^{4}$ Cf. ARANGUREN, José Luiz L. Ética. Madrid. Revista de Occidente. 1959. P. 15-16.
} 
"lar"s; mas a dificuldade surge do fato de que os gregos escreviam a palavra de dois modos: éthos (com "e" minúsculo, "eta"), traduzida por "costume"; ou êthos (com "E" maiúsculo,"epsilon"), significando "propriedade do caráter". A primeira é a que serviu de base para a tradução latina Moral (= mores, costumes), perdendo o outro sentido da palavra (= caráter). Na década de 1980, $J$. Clotet afirmava que a ética pretende a perfeição do ser humano ${ }^{6}$ : se torna uma meta última a ser alcançada, não realizada no presente. A partir de 2000, alguns autores distinguem ética de moral e outros as identificam; para Adela Cortina e Emilio Martínez, a ética é filosofia moral - a parte da Filosofia que reflete sobre a moral ${ }^{7}$. A ética é mais ampla que a moral-nos diz João Arnoldo Gascho: ela se caracteriza por sua generalidade, enquanto a moral se refere ao modo de agir em situações concretas - pela ética, nos guiamos, e, pela moral, nós agimos ${ }^{8}$. Para Fábio Konder Comparato, os princípios éticos são normas objetivas, mas sempre correlacionadas a virtudes subjetivas; são normas teleológicas ${ }^{9}$...

Como vemos, conceituar ética não é fácil e seus conceitos têm se modificado nas últimas décadas. A tendência é afirmar que, quando tratamos do comportamento prático, estamos nos referindo à moral; quando refletimos sobre quais valores guiam os comportamentos, estamos nos referindo à ética - é o caso de Adolfo Sánchez Vázquez ${ }^{10}$ : de um lado, temos atos e formas de comportamento que chamamos "morais" e, do outro lado, "juízos", que aprovam ou desaprovam moralmente os atos.

\section{A crítica à ética antropocêntrica}

Nas últimas décadas, a sociedade contemporânea repensou alguns valores éticos que vinham sendo estipulados. Um deles foi o antropocentrismo moderno, movimento filosófico ainda muito presente em nossa sociedade e alicerçando vários valores e contra-valores. $\mathrm{O}$ antropocentrismo trouxe muitos avanços científicos, tecnológicos e culturais e muitos valores éticos;

\footnotetext{
${ }^{5}$ Cf. MOORE, G. E. Princípios Éticos. São Paulo. Abril Cultural. 1975. P. 4. Apud GOLDIM, José Roberto. "Ética”. In: http://www.ufrgs.br/bioetica/etica.htm.

${ }^{6}$ Cf. CLOTET, J. “Una introducción al tema de la ética”. In: Psico. 1986; 12(1) 84-92. Apud ibidem.

${ }^{7}$ Cf. CORTINA, A. MARTÍNEZ, E. Ética. São Paulo. Edições Loyola. 2005. P. 9.

${ }^{8}$ Cf. GASCHO, J. A. Do Mito ao Genoma. A Ética na Contramão da História. Editora Jaraguá do Sul. UNERJ. 2004. P. 14.

${ }^{9}$ Cf. COMPARATO, Fábio Konder. Ética - Direito, Moral e Religião no Mundo Moderno. Companhia das Letras. 2006.

${ }^{10}$ Cf. VÁZQUEZ, Adolfo Sánchez. Ética. Editora Civilização Brasileira. Rio de Janeiro. 2006. P. 15-17.
} 
entretanto, ao se transferir o centro, de Deus, para o homem, este passou a apresentar-se como o absoluto e as demais formas de vida foram excluídas, desvalorizadas e até instrumentalizadas. Segundo alguns críticos, o próprio "mito gênico" bíblico, interpretado literalmente, teria contribuído para a atual ameaça do meio ambiente natural ${ }^{11}$. Na verdade, a "ordem bíblica" dada ao ser humano é um apelo, no sentido de preservar os espaços de vida, mas nem sempre foi assim interpretado e comunicado...

Tem aumentado em nossos dias a consciência dos prejuízos diversos causados à natureza e suas causas, que ameaçam gravemente a vida; várias reações e atitudes conjuntas tem sido propostas para frear a destruição da natureza. Deve-se destacar a iniciativa, por exemplo, do Conselho Ecumênico de Igrejas, tomada em sua assembléia geral de Vancouver, em 1983, quando as Igrejas-membros e a Igreja Católica atenderam ao "processo conciliar do comprometimento mútuo em favor da justiça, da paz e da preservação da criação". Mas a consciência do problema e a disposição para efetivar reais mudanças não estão presentes em toda parte e de igual modo, como se revelou claramente por ocasião da conferência mundial sobre a temática em Seul, em 1990... Ou seja: apesar de toda a evidência dos limites da ética antropocêntrica, ela está ainda muito enraizada em nossos valores, juízos éticos e atitudes morais. Urge uma re-educação ética, onde o bio-centrismo seja valorizado; entendemos que as religiões mundiais possam oferecer uma ajuda nessa construção.

\section{A ética biocêntrica}

Algumas propostas à ética antropocêntrica tem surgido nas últimas décadas. Uma de destaque é chamada ética mundial, amplamente desenvolvida e divulgada pelo teólogo católico suíço Hans Küng, principalmente em sua obra Projeto Ethos Mundial, em $1990^{12}$. O conceito de ethos mundial refere-se ao todo do mundo da vida humana e indaga por normas válidas universalmente ${ }^{13}$. Küng diz que valores fundamentais devem ajudar a resolver

${ }^{11}$ Cf. SATTLER, Dorothea; SCHNEIDER, Theodor. “C. Doutrina da Criação”. In: SCHNEIDER, Theodor (org.). Manual de Dogmática. Volume I. Petrópolis: Vozes. 2008³. P. 115-116.

${ }^{12}$ Cf. Reportagem da REVISTA NOVOLHAR, "Küng recebe honoris causa e defende ética mundial”, publicada em 31 de outubro de 2007, às 13h. In: <http://www.novolhar.com.br/ noticia.php?id=4668. Fonte: www.alcnoticias.org $>$.

${ }^{13}$ Cf. ZILES, Urbano. "Projeto de uma Ética Mundial". Publicado em: Teocomunicação. Porto Alegre, v. 37, n. 156, p. 223-229. Jun. 2007. In: <http://revistaseletronicas.pucrs.br/teo/ojs/index. php/teo/article/viewFile/2703/2054>. 
problemas globais ${ }^{14}$ e postula uma coalizão entre crentes e não-crentes, a partir de alguns critérios: para que o ser humano seja humano, deve recorrer a um Incondicional, o Absoluto. Certas normas fundamentais de todas as religiões se concretizam nos cinco mandamentos da humanidade: não matarás, não mentirás, não furtarás, não praticarás imoralidade; respeitarás os pais e amarás os filhos e as filhas; além disso, observam a regra de ouro: não fazer ao outro o que não quer que se faça a si. As religiões possuem motivações éticas convincentes baseadas em figuras exemplares (Buda, Jesus Cristo, Confúcio, Lao-Tse ou Maomé). Küng propõe, então, o caminho ecumênico (ou autocrítico), cujo critério principal é o apelo à humanidade comum e aduz três critérios inter-religiosos: uma religião deve seguir critérios éticos gerais, seguir critérios religiosos gerais e seguir o critério cristão. Para Küng, não necessitamos de uma única religião, mas de uma ética universal, onde haja uma relação entre autonomia e teonomia. Mas, analisando a proposta de ética mundial de Küng, algumas questões são levantadas: essa proposta consegue, realmente, uma coalizão entre crentes e descrentes?; esse projeto não está baseado em critério especificamente cristão ${ }^{15}$; no fundo, ela não é, ainda, uma ética antropocêntrica?

Desde, principalmente, a década de 1990, o objeto primeiro da Ética passou a ser o da defesa da vida, em suas múltiplas formas e dimensões: foi o surgimento do biocentrismo. O filósofo Carlos Naconecy apresenta a Ética Biocêntrica como aquela que entende os seres vivos individuais como intrinsecamente valiosos ${ }^{16}$. A perspectiva biocêntrica denuncia que os sistemas éticos fundados sobre a racionalidade, autoconsciência ou senciência (= capacidade de sentir) se calam frente a organismos que têm, claramente, uma importância moral. É fato que a humanidade alterou profundamente a vida na Terra nos insignificantes $0,000002 \%$ do tempo que está no planeta... O autor usa uma imagem especialmente iluminadora: se a história da Terra fosse comparada a um filme com um ano

\footnotetext{
Neste artigo, o autor usa as referências: KÜNG, Hans. Projeto de ética mundial. São Paulo: Paulinas, $2001^{3}$. Idem. Para que um ethos mundial? São Paulo: Loyola, 2005. KÜNG, Hans; SCHMIDT, Helmut. Uma ética mundial e responsabilidades globais. São Paulo: Loyola, 2001. MÜLLER, Wolfgang E. Argumentationsmodelle der Ethik. Stuttgart: Kohlhammer, 2003.

${ }^{14}$ Cf. KÜNG, Hans. Projeto de ética mundial, ob. Cit., p. 7-83. Apud ZILES, Urbano, ob. Cit., p. 224-227.

${ }^{15}$ Cf. ZILES, Urbano. "Projeto de uma Ética Mundial", ob. Cit., p. 228-229.

${ }^{16}$ Cf. NACONECY, Carlos M. Sobre uma Ética da Vida: o Biocentrismo moral e a noção de Bio-respeito em Ética Ambiental. Tese Doutoral. Puc-Rio Grande do Sul. Porto Alegre, agosto de 2007. P. 4-13. In: <http://tede.pucrs.br/tde_busca/arquivo.php?codArquivo=894>.
} 
de duração (146 anos por segundo), começando em $1^{\circ}$ de janeiro, a vida teria aparecido em março, os organismos multicelulares em novembro, dinossauros em 13 de dezembro, mamíferos em 15 desse mês, Homo sapiens nos 11 minutos finais, e a civilização humana entraria em cena apenas no último minuto... No pensamento filosófico da antiguidade até recentemente, a ética ocupou-se com os valores ou fins que deveriam governar a conduta humana em relação a outros seres humanos; mas, quanto à atitude pessoal e social frente às outras formas de vida, ela tem se dado em termos de custo-benefício.

O expoente mais conhecido da Ética Biocêntrica é Albert Schweitzer, que denunciou: “... um homem é ético somente quando a vida, enquanto tal, for sagrada para ele, a vida das plantas e dos animais, bem como a dos seus companheiros humanos" "17. Com efeito, o Biocentrismo rejeita radicalmente as tradições antropocêntricas; por outro lado, devido a esta mesma radicalidade, uma Ética da Vida é acusada de ser irrealista. Podemos entoar majestosamente a frase "toda vida é preciosa" e não nos sentirmos comprometidos a atos de salvamento de folhas de grama prestes a serem pisoteadas num jardim... Geralmente, não paramos para pensar antes de salvar a vida de um ser humano ameaçado de morte iminente; mas por que isso se modifica quando se trata de uma vida não-humana?

A diferença axiológica e normativa entre o Biocentrismo Moral e uma Ética Conseqüencialista Humanista Prudencial é clara: para o Humanismo Prudencial, uma árvore importa porque ela nos beneficia (argumento antropocêntrico); o Biocentrismo Moral atenta para o bem das árvores por elas mesmas. Todos os seres vivos têm algum status moral simplesmente por estarem vivos: os micróbios são responsáveis pelos ciclos dos principais nutrientes e elementos químicos da biosfera; sem as bactérias, não haveria a fixação do nitrogênio da atmosfera e os humanos e outras formas de vida no planeta não poderiam existir; bactérias também são responsáveis pela operação do nosso sistema digestivo, fertilidade do solo e o crescimento de plantas... O Biocentrismo Moral (ou Ética Biocêntrica) é mais abrangente que a Ética Ambiental e também não significa aquilo que, comumente, se entende por Bioética (hoje, quase um sinônimo de Ética Médica): ele é uma corrente ética que toma, como intrinsecamente valiosos, os seres vivos individuais, desde organismos multicelulares racionais até os unicelulares não sencientes. Não se trata apenas de defender o status moral de coletividades ecológicas ou espécies biológicas, tampouco focar a Vida enquanto processo planetário do qual os seres vivos são parte...

${ }^{17}$ Ibidem. 
Existem Éticas da Vida que estabelecem um contraste: de um lado, com as tradições antropocêntricas e, de outro, com uma Ética Animal, que exclui os não-sencientes, como plantas e insetos. O Biocentrismo Moral pode ser defendido numa versão monista (como em Schweitzer e Taylor) ou pluralista (como em Goodpaster e Attfiield). A modalidade monista prega que todos os organismos vivos têm exatamente o mesmo status moral; em contraste, na versão pluralista, não há um pleno status para todos os seres vivos: quanto maior a complexidade de um organismo vivo, maior o seu significado moral. Uma crítica ao monismo biocêntrico é sua ineficácia na resolução de conflitos morais e dilemas éticos em cenários concretos de interação humano/não-humano: se tudo o que é vivo tem valor intrínseco, devemos, nas circunstâncias concretas da vida (como matar para comer), decidir no "cara ou coroa" quem deve viver? Mas podemos articular as duas posturas (monista e pluralista): prioridades morais podem ser construídas a partir dos interesses dos diferentes organismos, fundados em suas vulnerabilidades e necessidades, e, por sua vez, fundadas nas capacidades de cada tipo de forma de vida.

Optamos aqui pelo biocentrismo em substituição ao antropocentrismo, porque entendemos, hoje, ser a vida, em todas as suas manifestações, o primeiro alvo da defesa da ética. Evidentemente, a defesa da pessoa humana e de sua vida e dignidade estão incluídas no Biocentrismo: nós, humanos, somos um todo, chamados a nos relacionar com o todo do Universo. Mas, para haver uma real mudança ética, será preciso uma real tomada de atitude - toda a família humana deverá estar empenhada no processo de valorização da vida; para essa tarefa, por conseguinte, pedimos a ajuda das maiores religiões desse planeta!

\section{A ética biocêntrica e as cinco maiores religiões mundiais}

As maiores religiões mundiais são, em ordem: cristianismo, islamismo, hinduísmo, as religiões chinesas e budismo ${ }^{18}$. Percebemos que nem todos os elementos dessas religiões auxiliam a Ética Biocêntrica; importa destacar os que mais se aproximam; deixaremos o Cristianismo para o final. Nas considerações éticas do Islamismo, devemos ressaltar alguns elementos do Livro Sagrado e algumas doutrinas religiosas ${ }^{19}$. Para um muçulmano, o mundo é

\footnotetext{
${ }^{18}$ Cf. BRASIL ESCOLA. “As cinco maiores religiões”. In: <http://www.brasilescola.com/religiao/ as-cinco maiores-religioes.htm>.

${ }^{19}$ SUA PESQUISA. “História do Islamismo”. In: www.suapesquisa.com/islamismo. Acesso em: 8 de junho de 2011. CENTRO DE ESTUDOS E DIVULGAÇÃO DO ISLÃ. [Diversos]. In: <http://
} 
uma imensa teocracia: todos os aspectos da vida religiosa, moral, social estão submetidos à revelação dada a Maomé $^{20}$. O islam possui uma feição própria: é uma típica "religião do deserto", sendo suavizado apenas após os contatos com as culturas sedentárias da Mesopotâmia e da Pérsia. Podemos destacar como preceitos religiosos importantes no Islã e que colaboram com a ética biocêntrica: os elementos dogmáticos básicos (crença, confiança e submissão a Allah ["o Único"] e seus preceitos); Allah é criador e juiz, "causa primeira" (influência da cultura grega) - todos os seres já preexistem em Deus; e o desenvolvimento da paciência e da reflexão. Cristianismo e Islamismo pregam muitos conceitos semelhantes, como bondade, generosidade e justiça. A ética islâmica assume um sentido mais político no Islamismo, com seus princípios de valentia e cavalheirismo e a austeridade de vida, moralidade administrativa e comercial, interesse pelos pobres e órfãos.

O Hinduísmo é a religião mais antiga ${ }^{21}$; a Índia possui um politeísmo organizado, de caráter naturalista; o povo autóctone cultivava um animismo muito ligado à terra, com divinização da fecundidade; aos poucos, prevaleceu a tendência para formas religiosas menos abstratas e mais próximas do ser humano e, com o tempo, surgiu a fé em um deus pessoal (teísmo), cheio de amor e interesse pela humanidade (Krishna). Na verdade, a alma indiana oscila sempre entre o politeísmo mais complexo, o monismo mais rígido e o teísmo cheio de luz e de calor. Podemos destacar, como princípios fundamentais do hinduísmo que auxiliam uma ética biocêntrica: Dharman (o modo de ser e a eficiência natural das coisas terrenas e divinas; o hinduísmo concebe a alma como "parte integrante do cosmo" e, não, como "ser criado no tempo"); Rita (corresponde ao grego "cosmos" e tem o sentido de uma força primordial, que mantém a ordem nas coisas divinas e terrenas), Brahman (a essência do sagrado; ele é parte da trimurti [trindade]: Brahma [deus criador], Vishnu [deus solar, conservador, guardião do dharma - da ordem cósmica e social] e Shiva [deus renovador, senhor da vida e da morte]), Atman (alma; representa a consciência individual, reflexo da consciência universal), Manâs (espírito; um dos três elementos constitutivos do ser humano, intermediário entre a alma e o corpo (sharina); localiza-se no cérebro e é representado pela inteligência e pela imaginação). O hinduísmo é notavelmente ético, embora não apresente uma doutrina racionalmente estruturada: induz o ser humano a praticar uma

www.islam.org.br/CEDI_temas.htm>. Acesso em: 4 de junho de 2011.

${ }^{20}$ Cf. PIAZZA, Waldomiro O. Religiões da Humanidade. São Paulo: Loyola. 19913. P. 391s.

${ }^{21}$ Cf. ibidem. P. 246-272. 
elevada espiritualidade, que elimina pela raiz toda a ação violenta - o que levou os indianos a uma elevada moral social, com a prática da castidade, veracidade, compaixão, piedade e, principalmente, da "não-violência" (ahimsâ). A meditação é uma experiência religiosa, de valor místico ${ }^{22}$. Outras características podem ser a existência das sampradâya (as seitas, que revelam um pan-en-teísmo - tudo em Deus) e Vishnu (divindade que assume várias formas da natureza animal). Os hinduístas não acreditam em um Deus Criador, mas que todas as coisas surgiram do esquartejamento do Uno (emanação).

A China apresenta uma cultura diversificada ${ }^{23}$. O Confucionismo e o Taoísmo são considerados religiões chinesas, mas ambas começaram como filosofias e se diferenciaram. "Religiões tradicionais chinesas" é uma designação muito simples para designar um vasto conjunto sincretizado de crenças, práticas e valores de diferentes religiões orientais ${ }^{24}$. A religião popular chinesa era a religião oficial da China até ao fim da monarquia chinesa (1911); seu centro era o culto de Shang Ti, o ser supremo, o coordenador universal ${ }^{25}$; os crentes comuns prestavam culto e homenagem aos antepassados, às divindades menores e aos homens deificados (ex: Confúcio, Lao Zi e Buda); eles encaravam as suas inúmeras divindades como seres superiores, encarregados por Shang Ti de velar e cuidá-los. Os chineses primitivos eram animistas, com algumas infiltrações totemistas, mas as concepções religiosas diferem de região para região ${ }^{26}$. Merece referência o culto aos espíritos tutelares, como shung-Lui, protetor do lar, e Shê, espírito dos campos. São algumas características das religiões chinesas que poderiam colaborar com a ética biocêntrica: o Culto do céu (“T'ien") (que se tornou cada vez mais pessoal, com tendência monoteísta, reinando sobre todo o cosmo); a doutrina do Yin e do Yang (elementos masculino e feminino: a ação recíproca entre ambos dá origem a todos os seres e constituem o Tao, princípio de tudo o que existe); a doutrina das duas almas no humano: uma material ( $p o$ ), que, pela morte, integra outros seres materiais, e, outra, espiritual (huen), que sobe ao céu. Existem práticas divinatórias: o emprego de números, de desenhos simbólicos, de diagramas (koa), com nomes convencionais (céu, terra, sol, trovão,vento, monte, água parada, água corrente,...). Somente com o advento das

${ }^{22}$ Cf. PIAZZA, Waldomiro O., ob. Cit., p. 258s.

${ }^{23}$ Cf. WIKIPÉDIA. "Religião na China”. In: <http://pt.wikipedia.org/wiki/Religi\%C3\%A3o_ na_China>.

24 Cf. WIKIPÉDIA. "Religiões populares chinesas". In: <http://pt.wikipedia.org/wiki/ Religi\%C3\%B5es_populares_chinesas>.

${ }^{25}$ JOHN WU. Para além do Oriente e do Ocidente. São Paulo: Flamboyant, 1956. P. 155-156.

${ }^{26}$ Cf. PIAZZA, Waldomiro O., ob. Cit., p. 180-184. 
grandes dinastias foi promovida a unidade religiosa e moral: Dinastia de Hsia: culto dos seres transcendentes (protetores de montes, rios, regiões, vento, chuva, etc); culto dos antepassados; práticas divinatórias (exame do movimento dos astros, etc); Dinastia dos Shang: os títulos celestes passam a significar atributos divinos; Dinastia dos Sheu: a doutrina dos cinco Soberanos, representando as cinco regiões da terra (norte, sul, leste, oeste e centro); nas aldeias do interior, os xamãs $(W u)$ praticam, invocando os espíritos dos montes e das fontes; Dinastia dos Han: divindades mais cultuadas são o sol, a lua, os imperadores das primeiras dinastias, o patrono da agricultura, a patrona da sericultura, os espíritos do céu e da terra, a estrela do ano, os patronos da medicina, o deus da literatura, a estrela polar, a montanha de leste e os patronos de cidades e profissões.

O Budismo é uma religião e filosofia não-teísta, tendo muitas tradições, crenças e práticas baseados nos ensinamentos atribuídos a Buda (o "Iluminado", em sânscrito) ${ }^{27}$. Consiste no ensinamento de como superar o sofrimento e atingir o nirvana (estado total de plenitude e paz, por meio da disciplina mental e de uma forma correta de vida). O Budismo é dividido em dois grandes ramos: Theravada ("Doutrina dos Anciões") - o mais antigo ramo do budismo e Mahayana. Podemos destacar conceitos budistas importantes que implicam na Ética biocêntricạ: Sofrimento, suas causas e soluções; as Quatro Nobres Verdades (relativas ao sofrimento); o Nirvana (é a meta do budismo; é o apagar do fogo das paixões e a extinção do ego; é não necessitar mais reencarnar; é a paz absoluta; é a iluminação); as Dhyâna-Bodhisatvvas, que atuam como forças cósmicas no mundo fenomenológico; uma vez que o apego à vida é que gera a dor, o Budismo prega a reflexão, a ascese (que controla os impulsos vitais), para extinguir esse apego e uma vida de moderação.

Para o Cristianismo, a Escritura é Palavra de Deus: o que é sagrado nela é o fato de que continua sendo salvífico para os povos ${ }^{28}$. Jesus Cristo é a "boa-nova" da realização de uma nova Aliança entre Deus e o humano, designada "Reino de Deus" (Mt 28,20) ${ }^{29}$, que se apresenta como a realização de uma libertação global, estrutural e escatológica (Lc 3,15; 17,21; Mc 1,15). A inauguração do Reino por parte de Jesus comporta o anúncio profético da conversão de todos a Deus e é proclamação de felicidade para os pobres e sofredores (Lc 6,20-21). O projeto fundamental de Jesus é libertação para a

\footnotetext{
${ }^{27}$ DA SILVA, V. “Budismo". In: http://www.sepoangol.org/buda.htm. Acesso em: 7 de junho de 2011. Cf. PIAZZA, Waldomiro O., ob. Cit., p. 302s.

${ }^{28}$ Cf. GARCIA RUBIO, A. O Encontro com Jesus Cristo vivo. Paulinas. 1994. P. 11s.

${ }^{29}$ Cf. BOFF, Leonardo. Jesus Cristo libertador. Petrópolis: Editora Vozes. $1988^{12}$. P. 25s.
} 
vida. O Reino de Deus, inaugurado por Jesus, conserva sempre um caráter de totalidade e de universalidade e se transforma em exigência ética na "moral das bem-aventuranças" (Mt 5,3-9; 25, 31s; Lc 6,36). No Reino de Deus, a Lei antiga (=Decálogo) não é abolida, mas aperfeiçoada (Mt 5,17-20) e radicalizada (Mt 5,21-48: 19,16-22; Mc 10,17-22). Jesus enfatiza mais as grandes atitudes éticas que as minúcias de preceitos particulares (Mt 23,23; 9,13; Os 6,6) e concentra a Lei nos mandamentos do amor a Deus e ao próximo (Lc 10,25-28; Mt 7,12) e ao inimigo (Lc 10,29-37; 6,27-35; Mt 5,43-48). O Messias é aquele que realiza a libertação dos infelizes concretos ( $\operatorname{lc} 4,16$ 21), porque sua situação de injustiça ofende a Deus (cf. Lc 24,47; At 2,38; $5,31 ; 13,38)$. Na atitude que se toma diante do outro, se decide a salvação (Mt 25,31-46). A justiça também ocupa lugar central em seu anúncio (cf. Lc 16,9): Jesus apresenta uma crítica libertadora a todo poder que seja dominação (cf. Lc 22,25-28) e exige de seus seguidores uma atitude ainda mais perfeita diante do que já é eticamente bom (Mt 19,12). Conversão é a produção de relações modificadas em todos os níveis (Mt 10,25; 11,19; 21,31; 22,21; Lc 13,32; Mc 10,31). A oração que Jesus ensinou estipula que Deus é Pai de todos: formamos uma única família humana (Mt 6,9-13).

O caminho de Cristo é o caminho do Pai (cf. Ef 5,1.25; 2Cor 5,19; Jo $3,16 ; 1$ Jo 4,10$)^{30}$, que é Pai de todos. A estrutura profunda de toda a obra de Deus é o ideal de comunhão de muitos na unidade. Deus fez a humanidade una e seu plano é refazê-la una no Cristo e por seu Espírito (cf. LG 13). Protogênese e escatologia se encontram: o fim é visto desde o início, onde ele é colocado em estado de gérmen. Somente na escatologia será esboçada a unidade querida por Deus e restaurada pelo Cristo e se poderá dizer: $o$ homem está feito ${ }^{31}$ ! Somente então o Desejo de Deus $(\mathrm{Gn} 1,26)$ se realizará: o humano restituirá sua imagem a Deus, pronunciando plural e unanimemente: "Nosso Pai"! Em Jesus Cristo, Deus se engajou total e definitivamente por Sua criação: há uma destinação divina nela ${ }^{32}$. O Cristo, segundo Adão e cabeça da Criação, é o princípio da nova ordem das coisas criadas ${ }^{33}$; Ele é cabeça porque é pléroma (cf. Col 1,18-19), n’Ele habita a plenitude do ser divino

\footnotetext{
${ }^{30}$ Cf. CONGAR, Yves. Igreja serva e pobre. P. 26-28, inclusive nota no. 13. Idem. À mês frères. P. 33-35.

${ }^{31}$ TENNYSÓN. “The Making of Man”. In: The Death of Oneone and other Poems. 1982. Apud ibidem. P. 34. Idem. Sainte Église. Paris. 1963. P. 172-173.

${ }^{32} \mathrm{CF}$. LG n ${ }^{\circ}$. 48. Apud idem. À mes frères, ob. cit. P. 36, e nota $\mathrm{n}^{\circ} 36$.

${ }^{33}$ Cf. CONGAR, Yves. Introdução ao mistério da Igreja. P. 16-17.
} 
e do ser criado. Ele é, para toda a criação, um princípio de renovação e de comunicação de vida divina (cf. Ef 1,23; 3,19; 4,12s; Col 1,18-20; 2,9s; etc). Portanto, todas as coisas, em dependência do Cristo e d'Ele recebendo nova vida, são recapituladas (cf. Ef 1,9-10). O Cristo possui uma realeza total, cujo exercício integral tem, por efeito, o Reino ${ }^{34}$.

A Escritura cristã fala do caráter cósmico da Redenção de Cristo $^{35}$. No humano, o universo alcança a dignidade hipostática ou pessoal; por sua vez, o ser humano, ligado ao mundo, o transforma. No e pelo humano, o cosmo chega a seu fim: é uma união no destino, fundado, ao mesmo tempo, na unidade do Propósito do Pai em suas comunicações no Filho e no Espírito, e na unidade real do universo. A salvação é o resultado, em Deus, de toda sua Criação visível: toda a Criação é incluída objetivamente na Redenção obtida pelo Cristo ${ }^{36}$, o "segundo Adão" (escathos Adam, 1Cor 15,45), um humano de serviço, despojamento e ação de graças - um humano de comunhão, do "Deus tudo em todos" (1 Cor $15,28)^{37}$. "O último Adão é um Espírito que dá a vida" (1Cor 15,45). Deus será "tudo em todos", por Cristo (1Cor 15,22) e no Espírito. O caminho revelado por Ele é igual ao termo e não se chega ao termo quando tudo tiver voltado ao seu Princípio (cf. Jo 14,1-11; Ef 4,10: “Aquele que desceu, é o mesmo que subiu acima de todos os céus, a fim de encher todas as coisas") ${ }^{38}$. A escatologia cristã propõe a absoluta comunhão da Criação com Deus ${ }^{39}$.

\section{Referências Bibliográficas}

ARANGUREN, José Luiz L. Etica. Madrid. Revista de Occidente. 1959. BOFF, Leonardo. Jesus Cristo libertador. Petrópolis: Editora Vozes. $1988^{12}$. CLOTET, J. "Una introducción al tema de la ética”. In: Psico. 1986; 12(1); 84-92. COMPARATO, Fábio Konder. Ética - Direito, Moral e Religião no Mundo Moderno. Companhia das Letras. 2006.

CONGAR, Yves. Igreja serva e pobre. . À mes frères. Introdução ao mistério da Igreja.

\footnotetext{
${ }^{34}$ Cf. Idem. À mês frères. P. 47-48.

${ }^{35} \mathrm{Cf}$. Idem. Cette Église que j'aime. P. 46-47.

${ }^{36}$ Cf. ibidem, p. 55, inclusive nota no. 14.

${ }^{37}$ Cf. Idem. Igreja serva e pobre. P. 24-25.

${ }^{38}$ Cf. Idem. Introdução ao Mistério da Igreja. P. 93.

${ }^{39} \mathrm{Cf}$. Idem. À mes frères. P. 36.
} 
. Cette Église que j'aime. . Sainte Église. Paris. 1963.

CONSTITUIÇÃO DOGMÁTICA DO CONCÍLIO VARTICANO II Lumen Gentium.

CORTINA, A. MARTÍNEZ, E. Ética. São Paulo. Edições Loyola. 2005.

GARCIA RUBIO, A. O Encontro com Jesus Cristo vivo. Paulinas. 1994.

GASCHO, J. A. Do Mito ao Genoma. A Ética na Contramão da História. Editora Jaraguá do Sul. UNERJ. 2004.

JOHN WU. Para além do Oriente e do Ocidente. São Paulo: Flamboyant, 1956. KÜNG, Hans. Projeto de ética mundial. São Paulo: Paulinas, $2001^{3}$.

. Para que um ethos mundial? São Paulo: Loyola, 2005.

KÜNG, Hans; SCHMIDT, Helmut. Uma ética mundial e responsabilidades globais. São Paulo: Loyola, 2001.

MOORE, G. E. Princípios Éticos. São Paulo. Abril Cultural. 1975.

MÜLLER, Wolfgang E. Argumentationsmodelle der Ethik. Stuttgart: Kohlhammer, 2003.

PIAZZA, Waldomiro O. Religiões da Humanidade. São Paulo: Loyola. 1991². SATTLER, Dorothea; SCHNEIDER, Theodor. "C. Doutrina da Criação". In:

SCHNEIDER, Theodor (org.). Manual de Dogmática. Volume I. Petrópolis: Vozes. 20083.

TENNYSÓN. “The Making of Man”. In: The Death of Oneone and other Poems. 1982.

VÁZQUEZ, Adolfo Sánchez. Ética. Editora Civilização Brasileira. Rio de Janeiro. 2006.

\section{Referências Webliográficas}

BRASIL ESCOLA. "As cinco maiores religiões". In: < http://www.brasilescola. com/religiao/as-cinco maiores-religioes.htm $>$.

CENTRO DE ESTUDOS E DIVULGAÇÃO DO ISLÃ. [Diversos]. In: <http:// www.islam.org.br/CEDI temas.htm>. Acesso: 4/6/2011.

DA SILVA, V. "Budismo". In: <http://www.sepoangol.org/buda.htm>. Acesso em: 7 de junho de 2011.

GOLDIM, José Roberto. “Ética”. In: < http://www.ufrgs.br/bioetica/etica.htm>.

NACONECY, Carlos M. Sobre uma Ética da Vida: o Biocentrismo moral e a noção de Bio-respeito em Ética Ambiental. Tese Doutoral. Puc-Rio 
Grande do Sul. Porto Alegre, agosto de 2007. P. 4-13. In: < http://tede. pucrs.br/tde_busca/arquivo.php?codArquivo $=894>$.

PINKER, Steven. "A Moral Gene. Ethics Blog". In: $<$ http://www.ruderfinn. com/blogs/ethics/2008/01/a-moral-gene.html>. "Is There a Gene for Compassion?". In: <http://cogweb.ucla.edu/ Abstracts/Pinker_on_Wright_94.html $>$.

REVISTA NOVOLHAR, "Küng recebe honoris causa e defende ética mundial", publicada em 31 de outubro de 2007, às 13h. In: $<$ http://www.novolhar. com.br/noticia.php?id=4668>. Fonte: www.alcnoticias.org .

SUA PESQUISA. "História do Islamismo". In: $<$ www.suapesquisa.com/ islamismo. Acesso em: 8/6/2011>. "The moral gene". In: <http://www. indianexpress.com/news/the-moral-gene/16009/>.

WIKIPÉDIA. "Religião na China". In: < http://pt.wikipedia.org/wiki/Religi\%C3\%A3o na_China>.

"Religiões populares chinesas". In: $<$ http://pt.wikipedia.org/wiki/ Religi\%C3\%B5es_populares_chinesas $>$.

ZILES, Urbano. "Projeto de umaÉtica Mundial". Publicado em: Teocomunicação. PortoAlegre,v.37,n.156,p.223-229.Jun.2007.In: $<$ http://revistaseletronicas. pucrs.br/teo/ojs/index.php/teo/article/viewFile/2703/2054>.

Eva Aparecida Rezende de Moraes

Doutora em Teologia pela PUC-Rio

Professora do Departamento de Teologia da PUC-Rio Professora do Instituto Teológico Franciscano de Petrópolis

Artigo Recebido em 29/08/2011

Artigo Aprovado em 2911/2011 